\title{
POTENSI BAKTERI PSEUDOMONAS AERUGINOSA PADA PROSES BIODEGRADASI ALKIL BENZENA SULFONAT LINEAR (LAS) DALAM TIGA JENIS DETERGEN KOMERSIAL
}

\author{
Mamay Maslahat ${ }^{1}$, Farila Rakhmanika ${ }^{2}$, RTM Sutamihardja ${ }^{1}$
}

(Diterima tgl : 1

Disetujui tgl :

\begin{abstract}
The use of detergent in household and industry activity can increase environment pollution. The active substance, that commonly used in detergent is Linear Alkyl Benzene Sulphonate (LAS). The research aims was to study potency of Pseudomonas aeruginosa in biodegradation of LAS in three kinds of commercially detergent. This research use P. aeruginosa as decomposer agent and added (NH4)2SO4, KH2PO4, K2HPO4, and C6H12O6 as N, P and $C$ sources. The three kinds of commercially detergent were used as samples $(A, B$, and $C$ ) with $35 \mathrm{mg} / \mathrm{L}, 50 \mathrm{mg} / \mathrm{L}$, and $100 \mathrm{mg} / L$ test concentration. The decreasing of $L A S$ content in 30 days of biodegradation was determined with MBAS and used spectrofotometre Uv-Vis instrument at $\lambda 652 \mathrm{~nm}$. The result showed that in 30 days of biodegradation process at $35 \mathrm{mg} / \mathrm{l}$ test concentration of $A, B$, and $C$ detergent, produced LAS residue 3,62; 4,66; and $11,62 \mathrm{mg} / \mathrm{L}$ respectively. At $50 \mathrm{mg} / \mathrm{l}$ test concentration of $A, B$, and $C$ detergent, produced LAS residue 7,71; 11,88; and $21,16 \mathrm{mg} / \mathrm{L}$ respectively, and at $100 \mathrm{mg} / \mathrm{L}$ test concentration of $A, B$, and $C$ detergent, produced LAS residue 27,98; 37,54; and $66,81 \mathrm{mg} / \mathrm{L}$ respectively.
\end{abstract}

Keywords: Biodegradation, LAS, Pseudomonas aeruginosa, MBAS, spectrofotometre uv-vis

\begin{abstract}
ABSTRAK
Penggunaan deterjen dalam kegiatan rumah tangga dan industri dapat meningkatkan pencemaran lingkungan. Zat aktif yang umum digunakan dalam deterjen adalah Alkil Benzena Sulfonat Linear (LAS). Tujuan penelitian ini adalah untuk mengkaji kemampuan Pseudomonas aeruginosa dalam mendegradasi LAS yang terdapat pada tiga jenis detergen yang berbeda. Penelitian ini menggunakan Pseudomonas aeruginosa sebagai dekomposer dan menambahkan (NH4)2SO4, KH2PO4, K2HPO4, dan C6H12O6 sebagai sumber N, P, dan C. Sebagai sampel digunakan tiga jenis deterjen komersial (A, B, dan C) dengan variasi konsentrasi uji 35mg/L, 50mg/L, dan 100mg/L. Penurunan kadar LAS dalam detergen selama 30 hari proses biodegradasi ditetapkan secara Methylene Blue Active Substances (MBAS) dan menggunakan instrumen spektrofotometer Uv-Vis pada $\lambda 652 \mathrm{~nm}$. Hasil penelitian menunjukkan pada hari ke 30 proses biodegradasi deterjen $\mathrm{A}$, B, dan C dengan konsentrasi uji $35 \mathrm{mg} / \mathrm{L}$ menghasilkan residu LAS berturut-turut sebesar 3,62; 4,66 dan 11,62 mg/L. Pada konsentrasi uji $50 \mathrm{mg} / \mathrm{L}$, residu LAS pada deterjen A, B, dan C berturut-turut sebesar 7,71; 11,88; dan 21,16mg/L. Sedangkan pada konsentrasi uji 100mg/L, residu LAS pada deterjen A, B, dan C berturut-turut sebesar 27,98; 37,54; 66,81mg/L.
\end{abstract}

Kata kunci: Biodegradasi, LAS, Pseudomonas aeruginosa,MBAS, spektrofotometer Uv-Vis.

\section{PENDAHULUAN}

Deterjen adalah surfaktan anionik dengan gugus alkil C9-C15 atau garam natrium berantai panjang dari sulfonat atau sulfat (RSO3-Na+ dan ROSO3-Na+)(1). Deterjen mengandung 10\%-30\% surfaktan di samping fosfor dan pemutih. Deterjen memberikan kontribusi fosfat sekitar $50 \%$ dari seluruh fosfat yang berada di perairan (2).

Deterjen memiliki kemampuan untuk menghilangkan berbagai kotoran yang menempel pada kain, alat-alat rumah tangga, dan peralatan lainnya. Oleh karena itu, deterjen masuk ke badan air sebagai buangan rumah tangga atau sering disebut dengan limbah

\footnotetext{
${ }^{1}$ Jurusan Kimia FMIPA Universitas Nusa Bangsa Bogor. Jl. KH Soleh Iskandar KM 4 Cimanggu Tanah Sareal Bogor 16166 Telp. (0251)8340217, Fax : (0251)7535605

${ }^{2}$ Laboratorium Bogor Labs, Dramaga Bogor
} 
domestik. Penggunaan deterjen bersifat kontinyu (terus menerus) dan menyebabkan ketergantungan. Limbah deterjen bertambah seiring dengan bertambahnya jumlah penduduk. Limbah ini membuat permukaan badan air tertutup busa.

Busa-busa di permukaan air menjadi salah satu penyebab kontak antara udara dengan air terbatas sehingga menurunkan kadar oksigen terlarut dan dapat menyebabkan mikroorganisme air kekurangan oksigen. Umumnya surfaktan berinteraksi dengan membran dan enzim. Toksisitas timbul dari penghambatan enzim atau transmisi selektif ion - ion melalui membran. Sesuai dengan waktu ketahanan surfaktan yang cukup singkat dalam daerah perairan, maka surfaktan tidak mengalami biomagnifikasi dalam rantai makanan. Air yang mengandung surfaktan (2-4 mg/l), tidak dapat dideteksi perubahan apapun (3).

Akumulasi deterjen dalam perairan dapat meningkatkan harga Chemical Oxygen Demand (COD)/Kebutuhan Oksigen Kimiawi, Biologycal OxygenDemand (BOD)/ Kebutuhan Oksigen Biologi, dan angka permanganat, sehingga pengolahan limbah yang mengandung deterjen sangat tepat jika menggunakan teknik biologis karena pengolahan dengan teknik biologis bertujuan untuk menghilangkan atau mengurangi kandungan senyawa organik atau anorganik. Pengolahan biologis dapat dicapai dengan bantuan aktifitas mikroorganisme pengurai/ dekomposer yang disebut dengan proses biodegradasi (4).

Jenis surfaktan yang dominan digunakan saat ini adalah alkil benzena sulfonat linier
(LAS). LAS dinilai lebih ramah lingkungan dibandingkan jenis surfaktan sebelumnya yaitu alkil benzena sulfonat (ABS). Hal tersebut karena rantai alkil pada LAS adalah linier sementara rantai alkil pada ABS bercabang. Beberapa penelitian $(5 ; 6)$ membuktikan bahwa LAS dapat diuraikan oleh bakteri Staphylococcus epidermis, Enterobacter gergoviae, Staphylococcus aureus, Pseudomonas facili, Pseudomonas fluoroscens, Pseudomonas putida, Kurthiazopfii, dan sebagainya (5). LAS dapat didegradasi oleh bakteri Bacillus sp. dan Pseudomonas sp. dengan penambahan nutrien $\mathrm{N}$ dan $\mathrm{P}(6)$.

\section{METODOLOGI}

\section{Bahan dan Peralatan}

Bahan yang digunakan sebagai sampel adalah deterjen komersial dengan kode $\mathrm{A}$, $\mathrm{B}$, dan $\mathrm{C}$, yang mengandung bahan aktif LAS. Deterjen komersial yang digunakan sebagai sampel dipilih tiga deterjen yang berbeda dalam hal bahan pengisi. Deterjen A tidak mengandung zat aktif lain selain LAS. Deterjen B mengandung zat aktif lain yang berfungsi sebagai pelembut. Deterjen $\mathrm{C}$ mengandung zat aktif lain yang berfungsi sebagai pemutih. Ketiga jenis deterjen diujikan dalam tiga variasi konsentrasi yaitu $35 \mathrm{mg} / \mathrm{L}$; $50 \mathrm{mg} / \mathrm{L}$; dan $100 \mathrm{mg} / \mathrm{L}$ berdasarkan penelitian yang telah dilakukan sebelumnya(6).

Bahan yang digunakan untuk pereaksi di antaranya $\mathrm{CHCl} 3$, biru metilen, asam sulfat, penunjuk fenol ftalien, larutan pencuci MBAS, larutan pencerna, larutan asam sulfat-perak sulfat, kanji, natrium tiosulfat, mangan sulfat, natrium azida, nutrien, unsur mikro, glukosa, 
dan bakteri Pseudomonas aeruginosa yang berasal dari PT Australian Laboratory Service (ALS) Kanada

Alat yang dipakai adalah reaktor batch, inkubator, spektrofotometer uv-vis merk Shimadzu Seri UV 1200, kertas saring $0,45 \mu \mathrm{m}$, alat ekstraksi, neraca analitik, dan alat - alat gelas.

\section{METODE ANALISIS}

\section{Proses Biodegradasi}

Biodegradasi dilakukan dalam suatu reaktor batch. Tahap pertama adalah penambahan larutan nutrien ke dalam reaktor. Nutrien yang digunakan adalah (NH4)2SO4 sebagai sumber nitrogen $(\mathrm{N})$. KH2PO4 dan K2HPO4 sebagai sumber fosfor (P) dan glukosa sebagai sumber karbon (C). Keseluruh garam ini dilarutkan hingga sempurna oleh air suling dan $\mathrm{pH}$ larutan dibuat netral. Tahap kedua adalah penambahan Pseudomonas aeruginosa ke dalam reaktor. Sediaan bakteri ini berbentuk serbuk yang dikemas dalam cangkang kapsul. Serbuk dalam satu kemasan cangkang kapsul dilarutkan menjadi $1.000 \mathrm{ml}$ dan larutan ini mengandung bakteri sebanyak $108 \mathrm{sel} / \mathrm{ml}$ (6). Penambahan mikroba ke dalam reaktor adalah $6 \mathrm{ml}$ untuk $1.000 \mathrm{~mL}$. Suhu reaktor adalah $27 \mathrm{oC}$, proses pengadukan dilakukan pada $30 \mathrm{rpm}$, dan kondisi $\mathrm{pH}$ dipertahankan pada 6,5-7,5. Pengamatan dilakukan selama 1(satu) bulan terhadap penurunan kadar LAS.

Analisis Kadar LAS

Penetapan kadar LAS mengacu pada prosedur kerja dalam American Public Health Association (7), edisi 21, 5540B. Tahapan analisis dalam penetapan kadar LAS dimulai dari penyaringan dengan kertas saring
$0,45 \mu \mathrm{m}$, pewarnaan dengan biru metilen, ekstraksi dengan $\mathrm{CHCl} 3$ sebanyak tiga kali dengan volume pengekstrak sebanyak $30 \mathrm{ml}$, setelah itu dilakukan pemisahan antara fase air dan fase $\mathrm{CHCl3}$, fase $\mathrm{CHCl} 3$ selanjutnya dicuci dengan larutan asam, setelah itu dilanjutkan dengan pengukuran intensitas dengan spektrofotometer uv-vis pada panjang gelombang $652 \mathrm{~nm}$. Kadar LAS selanjutnya dihitung berdasarkan rumus berikut :

$\operatorname{Kadar} \operatorname{MBAS}(\mathrm{mg} / \mathrm{L})=\mathrm{C}$ x fp

Dimana :

$\mathrm{C}=($ Absorbansi - intersep $) /$ Slope

$\mathrm{Fp}=$ Faktor Pengenceran

\section{HASIL DAN PEMBAHASAN}

\section{Biodegradasi LAS dengan Variasi Jenis Deterjen}

Deterjen A hanya mengandung zat aktif LAS tanpa menggunakan bahan aktif lain. Deterjen ini lebih cepat terurai dibandingkan kedua jenis deterjen lainnya pada konsentrasi yang sama (Gambar 1, Gambar 2, dan Gambar 3). Deterjen B adalah deterjen yang mengandung zat aktif lain yang berfungsi sebagai pelembut. Bahan yang umum digunakan sebagai pelembut adalah natrium fosfat (Na3PO4), asam sitrat, zeolit, dan etilen diamin tetra asetat (EDTA) (8). Bahan ini merupakan bahan kimia yang relatif mudah didegradasi tetapi pada konsentrasi tertentu zat-zat ini akan menghambat penguraian LAS.

Deterjen $\mathrm{C}$ adalah deterjen yang mengandung zat aktif selain LAS yang berfungsi sebagai pemutih. Senyawa yang umum ditambahkan adalah boraks, klorin, natrium hipoklorit, dan hidrogen peroksida (H2O2) (8). Senyawa- 
senyawa ini bersifat antibakteri sehingga sangat menghambat kerja bakteri bahkan mampu mematikan bakteri. Pengaruh variasi jenis deterjen terhadap proses biodegradasi diperlihatkan pada Gambar 1, 2 dan 3.

\section{Variasi Jenis Deterjen pada Konsentrasi Sampel Uji 35 mg/L}

Ketiga jenis deterjen menunjukan penurunan kadar LAS yang optimum pada hari ke-5. Penurunan kadar LAS pada deterjen A, B, dan $\mathrm{C}$ dengan konsentrasi uji $35 \mathrm{mg} / \mathrm{L}$, berturutturut adalah 65,$45 ; 62,20 ;$ dan 41,44\%. Hasil penelitian Efendi (2) menunjukan bahwa pada waktu 5 hari bahan organik yang terkandung dalam limbah domestik mampu terurai sekitar $65 \%$, sedangkan bahan organik yang lebih kompleks hanya teroksidasi sekitar $45 \%$.

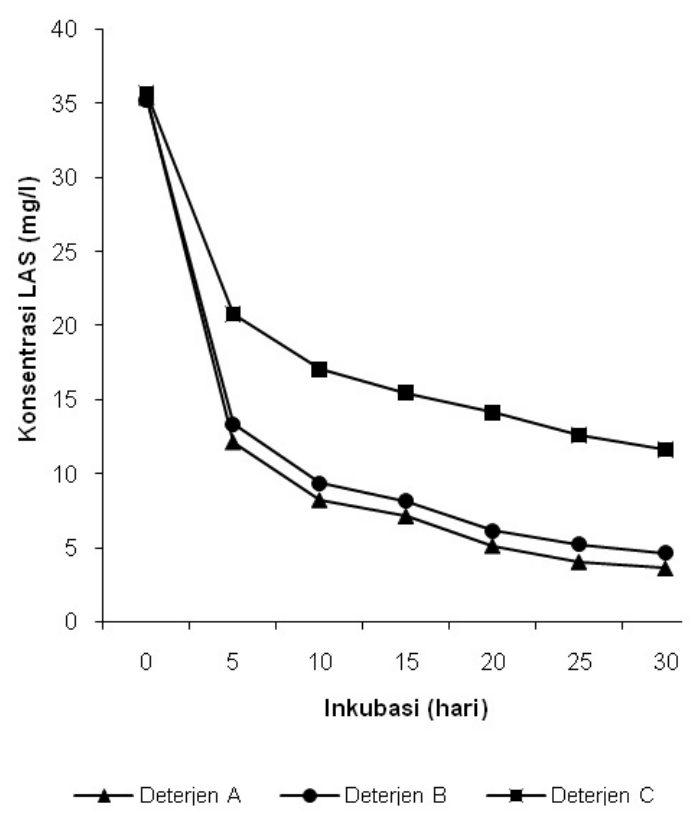

Gambar 1: Grafik Penurunan Kadar LAS pada Konsentrasi Sampel Uji 35 mg/L

\section{Variasi Jenis Deterjen pada Konsentrasi} Sampel Uji 50 mg/L

Deterjen A masih mengalami penurunan tertinggi. Penyebab utama adalah keberadaan bahan pengisi dalam deterjen $\mathrm{B}$ dan $\mathrm{C}$. Biodegradasi umumnya sangat ditentukan oleh sifat dan susunan bahan dan pada umumnya senyawa organik lebih mudah terurai dari pada senyawa anorganik. Tetapi dalam kenyataannya, khususnya di lingkungan alami biodegradasi ditentukan pula oleh banyak faktor baik yang bersifat biotik maupun abiotik (9). Biodegradasi LAS melibatkan beberapa enzim yang terdapat di dalam sel. Proses biodegradasi melibatkan proses $\beta$-oksidasi rantai hidrokarbon paling ujung, yang akan menghasilkan asam karboksilat (10).

\section{Variasi Jenis Deterjen pada Konsentrasi Sampel Uji $100 \mathrm{mg} / \mathrm{L}$}

Deterjen $\mathrm{C}$ mengalami penurunan terendah dibandingkan kedua jenis deterjen lainnya. Kandungan zat pemutih dalam deterjen ini sangat meminimalkan angka biodegradasi pada seluruh konsentrasi LAS. Senyawa pengelantang yang bersifat memutihkan umumnya menghambat pertumbuhan mikroba bahkan mematikannya. Terhambatnya pertumbuhan mikroba, menyebabkan produksi enzim pendegradasi pun menurun sehingga kemampuan degradasi terhadap deterjen akan lebih rendah.

Hampir semua bakteri mampu mengkatabolisis LAS sehingga menyebabkan perubahan struktur yang bervariasi pada rantai alifatik LAS. Bakteri yang mengubah LAS lambat laun akan mengalami penurunan kinerja kerja dalam hal mengoksidasi LAS selama proses biodegradasi berlangsung. Bakteri ini masih mampu mengoksidasi rantai karbon pendek seperti alkohol, aldehid, dan karboksilat tetapi tidak mampu mendegradasi LAS. Kosubstrat dapat menggantikan kerja bakteri yang mulai melemah (9). 


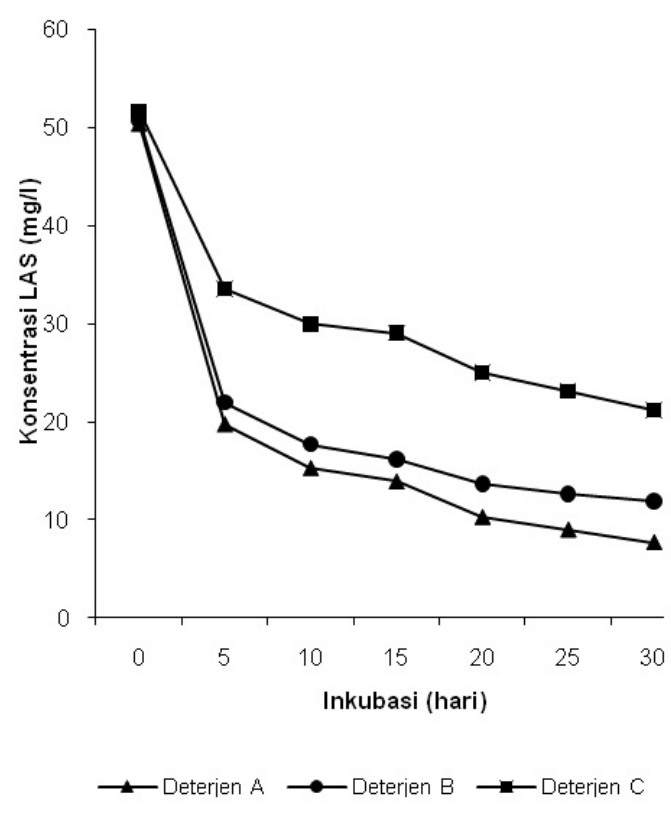

Gambar 2: Grafik Penurunan Kadar LAS pada Konsentrasi Sampel Uji $50 \mathrm{mg} / \mathrm{L}$

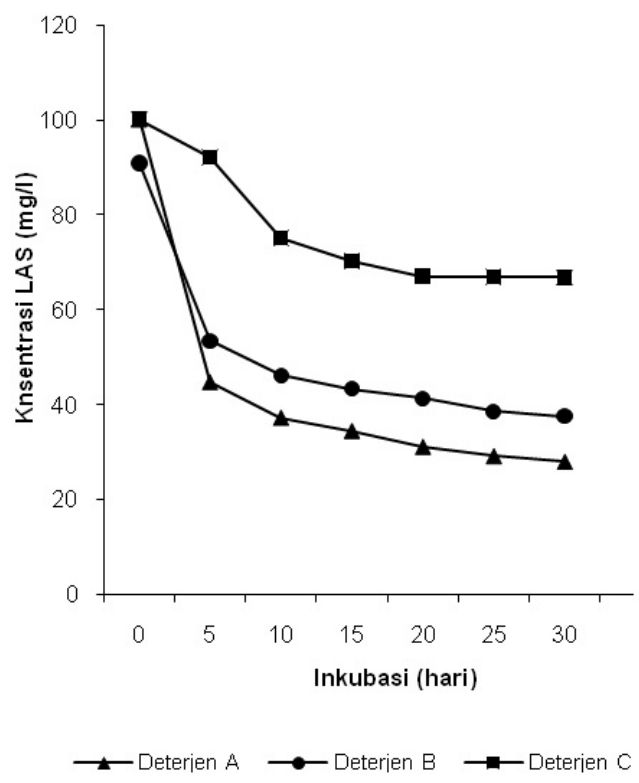

Gambar 3: Grafik Penurunan Kadar LAS pada Konsentrasi Sampel Uji $100 \mathrm{mg} / \mathrm{L}$

Proses biodegradasi berlangsung selama 30 hari. Pada hari ke 30 proses biodegradasi deterjen $\mathrm{A}, \mathrm{B}$, dan $\mathrm{C}$ dengan konsentrasi uji $35 \mathrm{mg} / \mathrm{L}$ menghasilkan residu LAS berturutturut sebesar 3,62; 4,66 dan 11,62 mg/L. Pada konsentrasi uji $50 \mathrm{mg} / \mathrm{L}$, residu LAS pada deterjen $\mathrm{A}, \mathrm{B}$, dan $\mathrm{C}$ berturut-turut sebesar 7,71; 11,88; dan 21,16 mg/L. Sedangkan pada konsentrasi uji $100 \mathrm{mg} / \mathrm{L}$, residu LAS pada deterjen $\mathrm{A}, \mathrm{B}$, dan $\mathrm{C}$ berturut-turut sebesar 27,98; 37,54; 66,81mg/L.

\section{Biodegradasi LAS dengan Variasi Kon- sentrasi}

Hubungan antara pertumbuhan spesifik (m) dengan konsentrasi substrat dimana $\mathrm{m}$ yang diukur pada suhu $30^{\circ} \mathrm{C}$ dan $\mathrm{pH}$ awal 4, menunjukkan bahwa pada konsentrasi susbstrat rendah maka m juga rendah (11).

Peningkatan konsentrasi substrat akan meningkatkan harga $\mathrm{m}$. Hal tersebut menunjukkan bahwa LAS dapat diubah menjadi biomassa. Penambahan substrat yang mudah diserap (nutrien) dan substrat yang dibutuhkan oleh bakteri, sangat diperlukan terutama untuk pembentukkan biomassa dan sintesis enzim yang diperlukan untuk pemecahan molekul deterjen. Biomassa yang di dalamnya kaya akan kandungan lemak, karbohidrat, dan protein merupakan hasil yang sangat bermanfaat bagi kelangsungan proses serta kehidupan makhluk lain, sebagian biomassa lainnya menjadi sediaan untuk produksi sumber karbon atau energi (11).

Kecepatan absorpsi substrat berpengaruh terhadap m. Salah satu faktor penentu kecepatan absorpsi substrat adalah berat molekul senyawa yang diserap. Bobot molekul LAS sekitar $249 \mathrm{~g} / \mathrm{mol}$. Berat tersebut lebih rendah dari berat molekul senyawa yang dapat diserap oleh dinding sel yaitu sekitar $600 \mathrm{~g} /$ mol. Teknik biodegradasi dapat digunakan untuk mengolah limbah yang mengandung deterjen dengan komposisi utama LAS 
maksimum sekitar 200 mg/L (11).

\section{Variasi Konsentrasi pada Deterjen A}

Berdasarkan grafik pada Gambar 4, dapat dikatakan bahwa efisiensi biodegradasi hanya berlangsung selama 10 hari karena sejak hari ke 15 hingga hari ke-30, penurunan terlihat tipis. Penurunan kadar LAS pada deterjen A dengan konsentrasi uji $35 \mathrm{mg} / \mathrm{L}$ pada hari ke $0,5,10,15,20,25$, dan 30 berturut-turut adalah 35,$36 ; 12,13 ; 8,22 ; 7,14 ; 5,14 ; 4,05$; dan 3,52 mg/L. Penurunan kadar LAS pada konsentrasi uji $50 \mathrm{mg} / \mathrm{L}$ pada hari ke $0,5,10$, 15, 20, 25, dan 30 berturut-turut adalah 50,37; 19,73; 15,26; 13,90; 10,28; 8,99; 7,71 mg/L. Dan Penurunan kadar LAS pada konsentrasi uji $100 \mathrm{mg} / \mathrm{L}$ pada hari ke $0,5,10,15,20,25$, dan 30 berturut-turut adalah 100,20; 44,79; 37,28; 34,50;31,15; 29, 19; 27,98 mg/L. Hasil penelitian Suharjono dkk (6) menunjukan bahwa biodegradasi LAS oleh Bakteri Pseudomonas sp. dilakukan dengan waktu pengamatan yang hanya berlangsung selama
12 hari.

Proses biodegradasi LAS tertinggi pada deterjen A mencapai 89 \% kemungkinan terjadi reaksi penguraian yang sempurna terhadap LAS. Mekanisme reaksi biodegradasi LAS beserta produk degradasi yang dihasilkan disajikan pada Gambar 5.

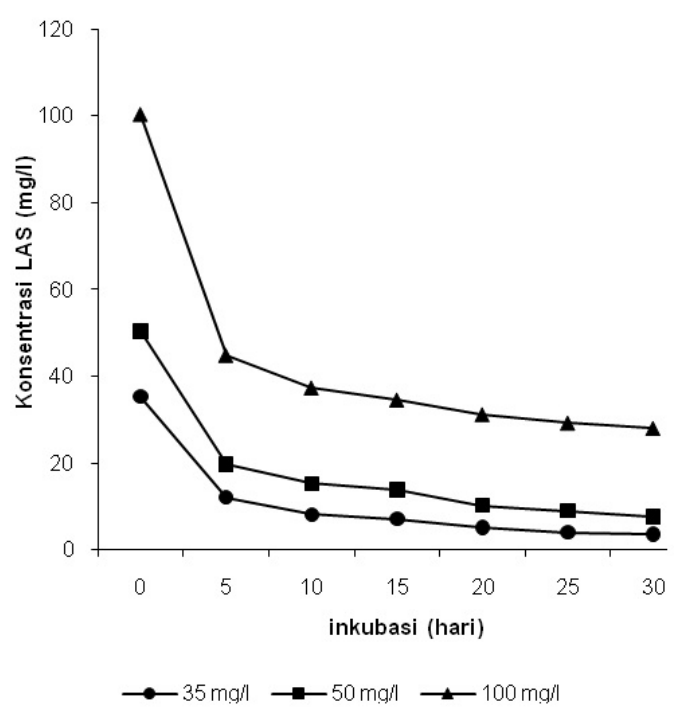

Gambar 4: Grafik Penurunan Kadar LAS pada Deterjen A
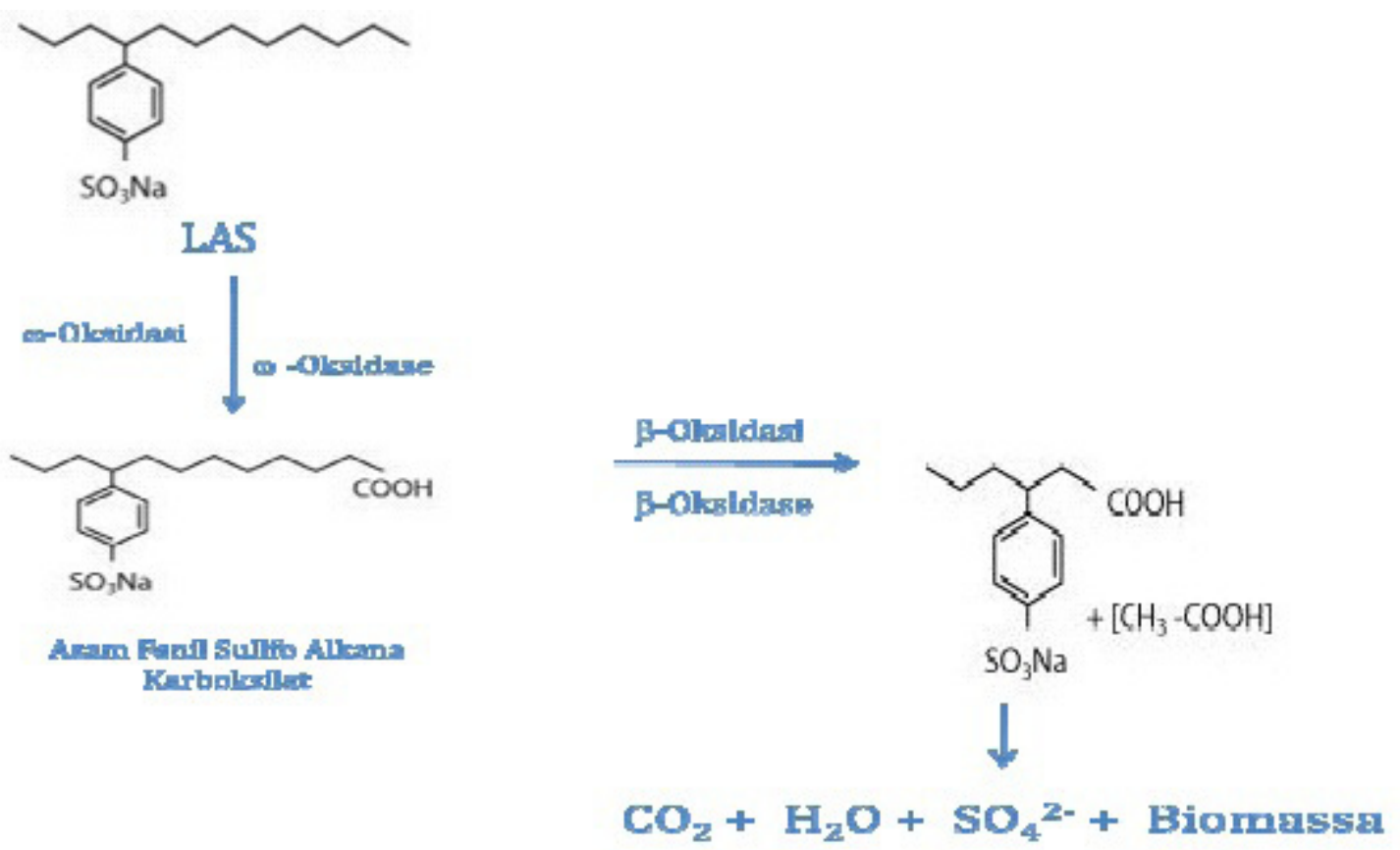

Gambar 5: Reaksi Lengkap Biodegradasi LAS ${ }^{(12)}$ 


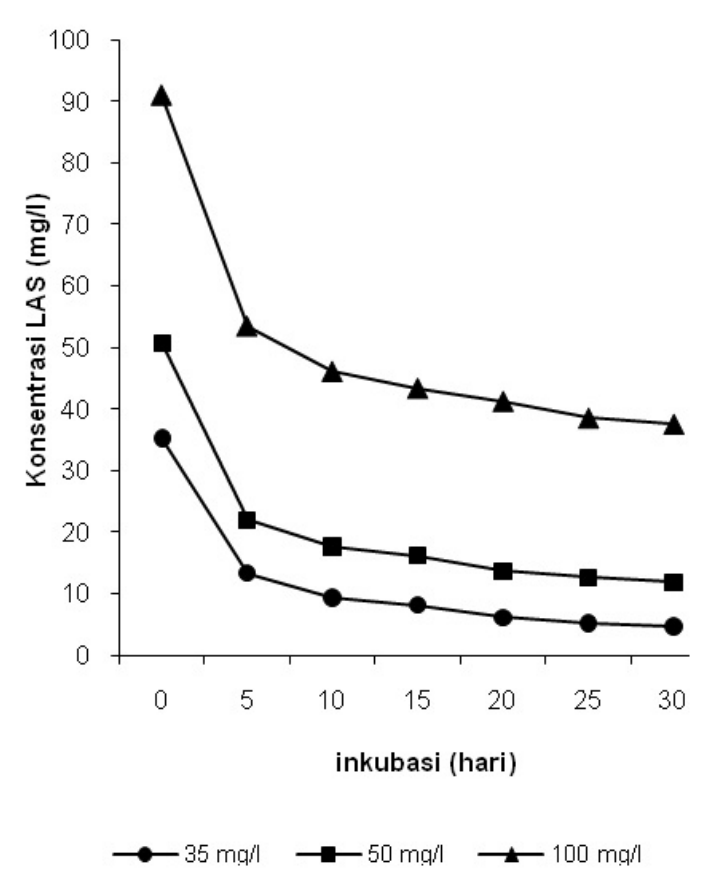

Gambar 6: Grafik Penurunan Kadar LAS pada Deterjen B

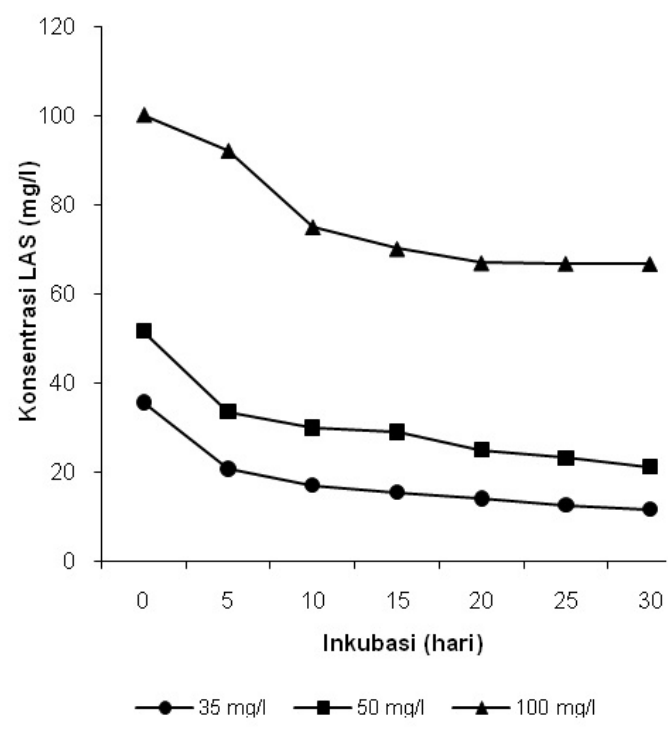

Gambar 7: Grafik Penurunan Kadar LAS pada Deterjen $\mathrm{C}$

\section{Variasi Konsentrasi pada Deterjen B}

Konsentrasi LAS $35 \mathrm{mg} / \mathrm{L}$ memberikan penurunan sebesar $86 \%$ kemungkinan reaksi biodegradasi berjalan lengkap. Pada konsentrasi $50 \mathrm{mg} / \mathrm{L}$ dan $100 \mathrm{mg} / \mathrm{L}$ penurunan berkurang yaitu sebesar 60-76\% kemungkinan reaksi hanya berjalan sampai pada reaksi $\beta$-oksidasi.

\section{Variasi Konsentrasi pada Deterjen $C$}

Deterjen $\mathrm{C}$ dengan konsentrasi uji tertinggi $(100 \mathrm{mg} / \mathrm{L})$ hanya menghasilkan penurunan sebesar 33,33 \%. Nilai ini lebih kecil dibandingkan pada percobaan lainnya. Hal ini dapat disebabkan oleh adanya kandungan pengelantang. Jenis pengelantang yang terdapat dalam detergen $\mathrm{C}$ adalah hidrogen peroksida (H2O2). Pada konsentrasi LAS $100 \mathrm{mg} / \mathrm{L}$, maka konsentrasi pengelantang akan lebih tinggi dari dua konsentrasi lainnya dan dosis tersebut sangat bersifat toksik bagi mikroba sehingga mikroba tidak mampu bertahan hidup (mati).

Kinetika kimia penurunan konsentrasi LAS selama proses biodegradasi dapat dilakukan melalui penghitungan nilai konstanta laju reaksi dan waktu paruh ( $\mathrm{t} 1 / 2)$. Persamaan yang digunakan adalah orde pertama.

$-\mathrm{dCt} / \mathrm{dt}=\mathrm{k}$ Co atau $\ln (\mathrm{Ct} / \mathrm{Co})=-\mathrm{kt}$

Dimana Co dan $\mathrm{Ct}$ adalah konsentrasi LAS pada 0 dan $\mathrm{t}$ hari, secara berturut-turut dan $\mathrm{k}$ merupakan konstanta laju untuk degradasi. Berdasarkan hasil perhitungan dan grafik penurunan konsentrasi LAS selama proses biodegradasi diketahui bahwa waktu paruh (t1/2) untuk detergen A pada konsentrasi awal 35, 50, dan $100 \mathrm{mg} / \mathrm{l}$ berturut-turut sekitar 9,8 dan 7 hari. Sedangkan waktu paruh untuk deterjen B pada konsentrasi awal 30, 50, dan $100 \mathrm{mg} / 1$ berturut-turut sekitar 10,9 dan 7 hari. dan waktu paruh untuk deterjen $\mathrm{C}$ pada konsentrasi awal 30, 50, dan $100 \mathrm{mg} / \mathrm{L}$ berturut-turut sekitar 11, 7 dan 6 hari. 


\section{KESIMPULAN}

Bakteri Pseudomonas aeruginosa mampu mendegradasi LAS. Ketiga jenis deterjen menunjukan penurunan kadar LAS yang optimum pada hari ke-5. Pada hari ke 30 proses biodegradasi deterjen $\mathrm{A}, \mathrm{B}$, dan $\mathrm{C}$ dengan konsentrasi uji 35mg/L menghasilkan residu LAS berturut-turut sebesar 3,62; 4,66 dan 11,62 mg/L. Pada konsentrasi uji 50 $\mathrm{mg} / \mathrm{L}$, residu LAS pada deterjen A, B, dan $\mathrm{C}$ berturut-turut sebesar 7,$71 ; 11,88$; dan 21,16mg/L. Sedangkan pada konsentrasi uji $100 \mathrm{mg} / \mathrm{L}$, residu LAS pada deterjen A, B, dan $\mathrm{C}$ berturut-turut sebesar 27,98; 37,54; $66,81 \mathrm{mg} / \mathrm{L}$.

\section{DAFTAR PUSTAKA}

(1). Fessenden, R.J. dan J.S. Fessenden. 1994. Kimia Organik. Edisi Ketiga. Jilid 1 dan 2. Jakarta: PT Erlangga.

(2). Effendi, H. 2003. Telaah Kualitas Air. Jakarta: Kanisius.

(3). Mason, C.F. 1993. Biology of Freshwater Pollution. Edisi Kedua. New York: Longman Scientific and Technical.

(4). Arifin. 2007. Tinjauan dan Evaluasi Proses Kimia (Koagulasi, Netralisasi, Desinfeksi) di Instalasi Pengolahan Air Minum Cikokol Tangerang. Laporan Kunjungan. Tangerang: PT Tirta Kencana Cahaya Mandiri.

(5). Wignyanto. 2002. Biodegradasi Alkil Benzena Sulfonat Pendekatan Eksperimental Laboratorik Untuk Pengolahan Limbah. Disertasi.
Surabaya: Universitas Airlangga.

(6). Suharjono, J., L.Subagja, C. Sembiring, Retnaningdyah, IKJW Putra. 2007. Pengaruh Konsentrasi Nitrogen dan Fosfor Terhadap Potensi Pseudomonas Pendegradasi Alkil Benzena Sulfonat Linier (LAS). Malang: Fakultas Biologi Universitas Brawijaya.

(7). Standar Method-APHA. 2001. Standard Methods for the Examination of Water and Waste Water. Edisi 21. USA: American Public Health Association.

(8). Badan POM. 2003. Deterjen. Info POM. Volume IV. Edisi 9. Jakarta: Badan Pengawasan Obat dan Makanan.

(9). Suriawiria, U. 1993. Mikrobiologi Air dan Dasar - Dasar Pengolahan Buangan Secara Biologis. Bandung: ITB.

(10).Kertesz, M.A., P.K. lbener, H.Stockinger, S. Beil, dan A.M. Cook. 1994. Desulfonasi surfaktan LAS dan senyawa serupa oleh bakteri. Appl. Environment Microbiol. 60: 2296-303.

(11). Sudiana, I.M. 2004. Peran Komunitas Mikroba Lumpur Aktif dalam Perombakkan Deterjen Alkilbenzenasulfonat linier benzena alkil sulfonat. Pusat Penelitian Biologi LIPI. Jakarta.

(12). Schoberl, P., E. Kunkel, dan K.J. Bock. 1989. Basic Principles of LAS Biodegradation. Munchen: Huls AG, Marl, FRG environmental protection. 